\title{
Site U1321
}

\author{
Expedition 308 Scientists $^{2}$
}

\section{Chapter contents}

Background and objectives........... 1

Summary of operations. . . . . . . . . 2

Downhole measurements........... 2

Figures...................

Tables...................... 16

'Expedition 308 Scientists, 2006. Site U1321. In Flemings, P.B., Behrmann, J.H., John, C.M., and the Expedition 308 Scientists, Proc. IODP, 308: College Station TX (Integrated Ocean Drilling Program Management International, Inc.). doi:10.2204/iodp.proc.308.105.2006

'Expedition 308 Scientists' addresses.

\section{Background and objectives}

\section{Geological setting of Brazos-Trinity Basin IV}

The geological framework of Brazos-Trinity Basin IV is described in the "Site U1319" chapter. The reader is referred to this chapter regarding necessary background information, along with an extensive compilation of presite data in figures and tables (Figs. F1, F2, F3, F4, F5, F6, F7, F8 in the "Site U1319" chapter; Table T1 in the "Site U1319" chapter).

\section{Overview of seismically mapped surfaces}

Site U1321 is located in $1458 \mathrm{~m}$ water depth near the center of Brazos-Trinity Basin IV (see Fig. F4 in the "Site U1319" chapter). Two-dimensional (2-D) seismic data show that the drilling location is on the southern margin of a bowl-shaped basin (Fig. F4 in the "Site U1319" chapter). Site U1321 is located on seismic Line 3020 between Sites U1319 and U1320 (Fig. F4 in the "Site U1319" chapter). Prior to drilling we mapped six major reflectors (shown in Fig. F1) in the vicinity of Site U1321: from shallowest to deepest, the seafloor reflector (SF) and seismic Reflectors R10, R20, R30, R40, R50, and R60 (see also Table T1 in the "Site U1319" chapter). Below seismic Reflector R40, sediment packages have approximately equal thickness along seismic Line 3020 (Fig. F5 in the "Site U1319" chapter). We infer that these sediments were deposited before any local topography developed as a result of salt movement or other tectonic factors. At Site U1321, seismic Reflector R60 is at $\sim 2160 \mathrm{~ms}$ two-way traveltime (TWT) (174.5 meters below seafloor [mbsf]) and separates a well-stratified package above from an area of short and more chaotically oriented reflections below (Fig. F1; see also Figs. F5, F6, F7 in the "Site U1319" chapter; Table T1 in the "Site U1319" chapter). Seismic Reflector R50 at $2119 \mathrm{~ms}$ TWT (139.9 mbsf) is a prominent reflector at the center of this package. Seismic Reflector R40 at 2054 ms TWT (86.2 mbsf) defines the top of the constant-thickness units. Above this reflector, seismic Reflectors R30 (2036 ms TWT; $71.5 \mathrm{mbsf}$ ), R20 (2024 ms TWT; 61.8 mbsf), and R10 (1973 ms TWT; 21.2 mbsf) cap three wedge-shaped packages in this marginal position of Brazos-Trinity Basin IV.

\section{Local summary of borehole expectations}

A few meters of Holocene hemipelagic mud drape was expected to overlie uppermost Pleistocene muddy and sandy deepwater fan 
turbidites to a depth of $\sim 86 \mathrm{mbsf}$, roughly equivalent to the position of seismic Reflector R40 (Fig. F1). The wedge-shaped geometries of the reflective and seismically transparent packages lead to an interpretation that Site U1321 is the location of rapid thinning of the deepwater fan units cored at Site U1320. Between seismic Reflectors R40 and R60, the seismic signature extending from the southern flank of the basin indicates interbedded hemipelagic and turbidite muds of prefan age.

\section{Drilling objectives}

We drilled Hole U1321A as a dedicated loggingwhile-drilling/measurement-while-drilling (LWD/ MWD) hole. The principal objective was to facilitate correlation of lithostratigraphic units and individual sand layers across the south-southwest margin of Brazos-Trinity Basin IV and document the lateral change in petrophysical facies, especially of the deep-sea fan units above seismic Reflector R40. The results of LWD/MWD are documented in the following sections of this chapter.

\section{Summary of operations}

\section{Hole U1321A}

The summary of operations at Site U1321 can be found in Table T1. The JOIDES Resolution was offset from Hole U1319B by $0.6 \mathrm{nmi}$ to Hole U1321A (proposed Site BT4-3A) on a heading of $022^{\circ}$ at an average speed of $0.9 \mathrm{kt}$. The vessel was on station by midnight and a beacon was deployed at $0005 \mathrm{~h}$ on 13 June 2005. The driller tagged the seafloor at 1468.0 meters below rig floor (mbrf) (precision depth recorder $=1467.4 \mathrm{mbrf}$ ) and observed the spudding at $0205 \mathrm{~h}$ via the subsea camera. MWD drilling proceeded without incident to the depth objective of $140.0 \mathrm{mbsf}$ by $0900 \mathrm{~h}$ at a controlled rate of penetration (ROP) of $30.0 \mathrm{~m} / \mathrm{h}$. The bit was recovered and the MWD drilling package was disassembled, laid down, and secured for the sea voyage to the next site. The vessel departed for Ursa Basin and Site U1322 at $1500 \mathrm{~h}$ on 14 June. A complete description of MWD operations in Hole U1321A can be found in "Downhole measurements."

\section{Downhole measurements}

Hole U1321A was a LWD/MWD hole and the only hole drilled at Site U1321. The objectives were to:

1. Correlate lithostratigraphic units across the south-southwest margin of Brazos-Trinity Basin IV,
2. Determine the facies of turbidites for correlation with sections at Sites U1319 and U1320, and

3. Document the lateral change in petrophysical properties of the deep-sea fan units above seismic Reflector R40.

\section{Logging while drilling and measurement while drilling}

\section{Operations}

The same bottom-hole assembly and tool configuration assembled for Sites U1329 and U1320 were used for LWD operations in Hole U1321A (see "Operations" in the "Site U1320" chapter). The hole was started using a rapid jet-in penetration and pump rates of $\sim 55$ gallons per minute (gpm) from 0 to 20 mbsf before retrieving the vibration-isolated television camera. A controlled ROP of $30 \mathrm{~m} / \mathrm{h}$, bit rotation of $50 \mathrm{rpm}$, and pump rates of $\sim 60 \mathrm{gpm}$ were used for drilling the upper 25 mbsf until all the LWD sensors were below the seafloor. Pump rates were then slowly increased, reaching $\sim 400$ gpm by $\sim 42$ mbsf, where the mud pulsing system began transmitting data to the surface. The hole was drilled to 140 mbsf.

\section{Logging data quality}

MWD/LWD operations in Hole U1321A reached 140 mbsf to provide data coverage by all LWD tools through the turbiditic and hemipelagic stratigraphic units drilled at Sites U1319 and U1320. Figure F2 shows the quality control logs for Hole U1321A. The target ROP of $30 \mathrm{~m} / \mathrm{h}( \pm 5 \mathrm{~m} / \mathrm{h})$ was achieved except for the upper $6.5 \mathrm{~m}$ of the hole, where rapid jet-in exceeded $370 \mathrm{~m} / \mathrm{h}$. The ROP slowed to $\sim 60 \mathrm{~m} / \mathrm{h}$ by $20 \mathrm{mbsf}$, followed by a steadier rate. Overall hole quality at shallow depths was variable with several high caliper measurements. The density-derived caliper $\log$ is near $25 \mathrm{~cm}$ toward the bottom of the hole. The bulk density correction varies from -0.04 to 0.15 $\mathrm{g} / \mathrm{cm}^{3}\left(\right.$ mean $\left.=0.01 \mathrm{~g} / \mathrm{cm}^{3}\right)$ (Fig. F2), which indicates that good-quality bulk density measurements were obtained except for intervals characterized by washouts.

Log depths, in mbsf, for the LWD logs were constrained by identifying the gamma ray signal at the seafloor. For Hole U1321A, the gamma ray log pick for the seafloor was at a depth of 1462.9 mbrf, $0.9 \mathrm{~m}$ deeper than the drillers depth. The rig floor logging datum was $10.5 \mathrm{~m}$ above sea level for this hole.

\section{Annular pressure while drilling and equivalent circulating density}

Annular pressure while drilling (APWD) within the borehole was monitored during MWD operations as 
annular pressure in excess of hydrostatic (APWD*) and equivalent circulating density referenced to the seafloor $\left(\mathrm{ECD}_{\mathrm{rsf}}\right)$ (see discussion in "Array resistivity compensated tool" in "Downhole measurements" in the "Methods" chapter). $\mathrm{ECD}_{\text {rsf }}$ decreased from 0 to 35 mbsf. At 35 mbsf, $\mathrm{ECD}_{\text {rsf }}$ increased from 9.5 pounds per gallon (ppg) to $12.5 \mathrm{ppg}$, which is also reflected as an increase in the APWD* to $0.25 \mathrm{MPa}$ (Fig. F3). We interpret that this increase is due to sediment from a $20 \mathrm{~m}$ thick sand interval loading the annulus. At $\sim 55$ mbsf the lithology changed to a clay-rich unit, and $\mathrm{ECD}_{\mathrm{rs}}$ and $\mathrm{APWD}^{*}$ returned to stable values as the cuttings were flushed from the borehole. The $\mathrm{ECD}_{\text {rsf }}$ and APWD* profiles below 55 mbsf do not show significant anomalies, suggesting that we did not drill through any permeable, overpressured units and that the borehole remained intact during operations.

\section{Results}

The GeoVision Resistivity (GVR) tool gamma ray log (GR) is highly variable in the upper 67 mbsf. Below 67 mbsf, GR values are nearly constant with a mean value of 72 gAPI, suggesting a clay-rich lithology. From the GR, we interpret a series of intercalated sand and clay intervals above $\sim 67$ mbsf. The most prominent stratigraphic marker is a $25 \mathrm{~m}$ thick sandrich interval located between 35 and $60 \mathrm{mbsf}$, where gamma ray values are as low as 11.4 gAPI. GVR deep button resistivity increases from 0.3 to $1.9 \Omega \mathrm{m}$ from the seafloor to 140 mbsf. Resistivity variations are interpreted as changes in sand and clay content. The most prominent feature below $67 \mathrm{mbsf}$ is a clay-rich unit between 85 and 93 mbsf that is bounded by $1 \mathrm{~m}$ thick silty sand intervals (Fig. F4).

The Vision Density Neutron tool bulk density log increases from $1.0 \mathrm{~g} / \mathrm{cm}^{3}$ at shallow depths to $2.0 \mathrm{~g} / \mathrm{cm}^{3}$ near the bottom of the hole (Fig. F4). Neutron porosity decreases from $85 \%$ to $45 \%$ with the largest porosity fluctuations occurring in sand-rich intervals (Fig. F4). Density and neutron porosity data suggest normal compaction. Density and neutron porosity values above 67 mbsf reflect the presence of sand units and correspond to enlarged borehole dimensions. The photoelectric factor (PEF) log follows similar trends as those observed in the gamma ray, resistivity, and density data. The PEF log shows systematic variations in the upper $67 \mathrm{~m}$ that we interpret as sharp changes in clay and sand content (Fig. F4).

\section{Definition and interpretation of logging units}

We conducted a preliminary lithologic interpretation in Hole U1321A based on gamma radiation, re- sistivity, and GVR resistivity-at-the-bit images (Fig. F5). Seismic correlation indicates that the lithology at Site U1321 should be similar to Sites U1319 and U1320. The correlation between lithology and log response at those sites shows that sands, clay, and silt/ silty sands can be distinguished based on gamma ray and resistivity. GVR resistivity images at Sites U1319 and $\mathrm{U} 1320$ also show that relatively thin $(\sim 5 \mathrm{~cm})$ sand and silty sand beds can be resolved in many cases. The nature of the bedding contacts, whether conformable or erosional, and, in some cases, contorted bedding can also be inferred from the GVR resistivity images at Site U1320.

Given the observations and initial correlation between lithology and log response at Sites U1319 and U1320, we defined thresholds for clay, silt, and sand as follows:

- Sand: gamma radiation < 35 gAPI; resistivity (RING) < 0.9 $\Omega \mathrm{m}$,

- Clay/Mud: gamma radiation > 55 gAPI; resistivity (RING) $>\sim 1.2 \Omega \mathrm{m}$,

- Silt: gamma radiation 35-55 gAPI; resistivity (RING) 0.9-1.2 $\Omega$ m.

At Sites U1319 and U1320 we penetrated hemipelagic foraminifer-bearing clays associated with lithostratigraphic Units III and V (at Site U1319). These clays had a slightly higher resistivity (up to $\sim 1.5 \Omega \mathrm{m}$ ) than adjacent clay intervals but similar gamma ray response. We used this distinctive signature to infer the presence of these hemipelagic intervals at Site U1321. Where thin beds are inferred from the GVR images, gamma radiation shows only minor deflections. The minor gamma ray response is due to bad resolution. Where thin beds are inferred, we infer grain size (silt or sand) from the RING resistivity curve, which has higher resolution than the gamma ray tool.

Logging units at Site U1321 were defined primarily from the gamma ray and resistivity curves using 1468 mbrf as the depth to the seafloor (Fig. F5). We defined two major logging units, with the upper unit (logging Unit 1) divided into four subunits $(1 \mathrm{a}, 1 \mathrm{~b}$, 1c, and 1d). Logging Unit 2 was not divided into subunits (Table T2).

\section{Logging Unit 1 (0-70.5 mbsf)}

Logging Unit 1 is defined by a highly variable gamma ray response ranging from $\sim 15$ to 75 gAPI and resistivity variation of $0.1 \Omega \mathrm{m}$ (Fig. F5). Logging Unit 1 is interpreted to contain five sand packages (P1-P5) interbedded with muddy intervals, with a net sand content of $\sim 60 \%$. In the uppermost $4 \mathrm{~m}$ of the hole ( $0-4 \mathrm{mbsf})$ we observe a gradual upward decrease in gamma radiation and resistivity. This is 
likely a consequence of hole enlargement and very porous sediments. With analogy to Hole U1320A, we interpret this interval to be silty with thin beds and laminae of sand, grading to a foraminifer-bearing clay at the top of the hole (Figs. F4, F5).

\section{Logging Subunit 1a (0-20 mbsf)}

Logging Subunit 1a contains sand Packages P1 and P2 with thicknesses of $6 \mathrm{~m}$ and $2 \mathrm{~m}$, respectively (Figs. F4, F5). These packages have sharp bases and gradational tops. Package P1 probably has three or more amalgamated sand beds. The muddy interval between Packages P1 and P2 is interpreted to contain thin sand and silt beds. This subunit is defined by covariation of gamma radiation and resistivity curves over intervals of several meters. Porosity and density display similar variations that support interpretation based on the gamma ray and resistivity curves (Fig. F4).

\section{Logging Subunit $1 b$ (20-32.5 mbsf)}

Logging Subunit $1 \mathrm{~b}$ is defined by a uniformly high gamma ray and resistivity response interpreted as predominantly mud. A slightly lower gamma ray response at the base of the subunit suggests higher silt content (Figs. F4, F5). Density has a pattern similar to those exhibited by the gamma ray and resistivity data, whereas porosity is predominantly lower than within the subunits above and below.

\section{Logging Subunit 1c (32.5-60.5 mbsf)}

Logging Subunit $1 \mathrm{c}$ is $26 \mathrm{~m}$ thick and consists almost entirely of sand Package P3 (Fig. F5). This package has a sharp base and a gradational top. At the top of the subunit, the GVR resistivity image suggests dipping surfaces, which are either related to erosional scours or deformed/folded beds. Within the package, subtle resistivity changes are interpreted to represent amalgamation surfaces. In the upper part of sand Package P3 we observe high resistivity in the GVR resistivity images (Fig. F5) that are interpreted as mud clasts. This subunit is defined by resistivity and gamma ray responses that drop over the upper $10 \mathrm{~m}$ of the interval and then remain low to the base. Density decreases and remains low throughout this subunit, whereas the opposite response is observed in porosity (Fig. F4).

\section{Logging Subunit 1d (60.5-70.5 mbsf)}

Logging Subunit 1d is composed of sand Packages P4 and P5, each $\sim 2 \mathrm{~m}$ thick (Figs. F4, F5). The packages have sharp bases, gradational tops, and appear to be composed of one to two sand beds each. Mud intervals within logging Subunit 1d appear to show laminations and contorted beds (Fig. F6). In this subunit, resistivity and gamma ray values vary over intervals of a maximum of $2-3 \mathrm{~m}$. Density and porosity also show similar responses throughout this subunit (Fig. F4). The top of this subunit is characterized by a thin clay-rich interval. Based on the check shot data from Hole U1320A, it appears that this clay-rich interval correlates with seismic Reflector R20.

\section{Logging Unit 2 (70.5-140 mbsf)}

Logging Unit 2 is dominated by clay and mud. Based on slightly higher resistivity, we interpret two intervals of hemipelagic clays at or below seismic Reflectors R30 and R40. The upper hemipelagic clay interval is $\sim 8 \mathrm{~m}$ thick, and the lower interval is $\sim 4 \mathrm{~m}$ thick. These intervals correlate well with foraminiferbearing clays cored below seismic Reflectors R30 and R40 at Site U1319 and below seismic Reflector R30 at Site U1320. The clay interval between 78.5 and 87 mbsf is interpreted to have thin sand or silt beds based on the resistivity data. Below 87 mbsf, logging Unit 2 appears to have small-scale variations in resistivity that are interpreted to represent centimeter- to decimeter-scale variations in clay and silt content. Steeply dipping surfaces found within this unit may represent deformation due to mass transport deposits or faulting (Fig. F6).

Overall, logging Unit 2 shows little variation in gamma ray and resistivity response. Gamma ray values generally track at $~ 75$ gAPI, with a few excursions reaching to slightly less than 60 gAPI. Resistivity is relatively high and uniform, generally tracking just higher than $1 \Omega \mathrm{m}$. From 70.5 to $78.5 \mathrm{mbsf}$ resistivity is locally elevated above background and gamma radiation is also slightly higher than background over this interval. Similar local positive anomalies in resistivity and gamma ray values occur from 87 to 94 mbsf. This latter feature is bound from 85 to 87 and 94 to 96 mbsf by the two significant excursions in gamma ray values.

\section{Physical properties from log data}

At Site U1321, LWD data provide estimates for sediment physical properties. Downhole profiles of density and density-derived porosity were used for stress analyses at this site assuming hydrostatic conditions.

\section{Density and porosity}

The LWD bulk density profile from Hole U1321A is used to derive porosity (Fig. F7A):

$$
\phi=\left[\left(\rho_{\mathrm{s}}-\rho_{\mathrm{b}}\right) /\left(\rho_{\mathrm{s}}-\rho_{\mathrm{sw}}\right)\right] \times 100,
$$

where

$$
\begin{aligned}
& \phi \quad=\text { porosity, } \\
& \rho_{\mathrm{s}}=\text { density of solids or grain density }\left(2.7 \mathrm{~g} / \mathrm{cm}^{3}\right), \\
& \rho_{\mathrm{b}}=\text { LWD bulk density, and }
\end{aligned}
$$


$\rho_{\mathrm{sw}}=$ density of seawater $\left(1.024 \mathrm{~g} / \mathrm{cm}^{3}\right)$.

The bulk density profile shows an overall increase with depth from 1.0 to $2.0 \mathrm{~g} / \mathrm{cm}^{3}$, which equates to porosity estimates decreasing from $85 \%$ to $45 \%$ (Fig. F7A). Based on these profiles, four distinct intervals can be distinguished in Hole U1321A. These intervals are highlighted by washouts and interpreted as sandy layers. Therefore, the data in the intervals underestimate the true bulk density.

Relatively low bulk densities averaging $\sim 1.35 \mathrm{~g} / \mathrm{cm}^{3}$ and high porosities $(\sim 85 \%)$ characterize the upper part of logging Subunit 1a (0-11 mbsf). A second interval, interpreted to be a clay-rich section, comprises the lower part of logging Subunit 1a, all of Subunit 1b, and the upper part of Subunit 1c (11-37 mbsf). This interval has higher bulk densities ( 1.7 g/ $\left.\mathrm{cm}^{3}\right)$ and lower porosities ( 60\%). The third interval, including most of logging Subunit 1c (37-59 mbsf) has lower densities $\left(\sim 1.25 \mathrm{~g} / \mathrm{cm}^{3}\right)$ and high porosities (85\%-90\%). At 60 mbsf, a sharp increase in bulk density, which correlates with seismic Reflector R20, marks the beginning of the fourth interval. In this interval there is a gradual increase in bulk density from $\sim 1.8$ to $1.9 \mathrm{~g} / \mathrm{cm}^{3}$. A few minor density peaks can be observed in this interval, and seismic Reflector R40 correlates with one of these peaks at 85 mbsf.

A vertical hydrostatic effective stress $\left(\sigma_{\mathrm{vh}}{ }^{\prime}\right)$ profile can be obtained from the bulk density (see "Physical properties" in the "Methods" chapter).

The high variations observed in the bulk density data (Fig. F7A) are translated to a nonlinear vertical effective stress profile (Fig. F7C). If bulk density is filtered to remove anomalously low bulk density $\left(\rho_{b}<\right.$ $1.5 \mathrm{~g} / \mathrm{cm}^{3}$ from 0 to $20 \mathrm{mbsf}$ and $\rho_{\mathrm{b}}<1.75 \mathrm{~g} / \mathrm{cm}^{3}$ below $20 \mathrm{mbsf}$ ), the vertical hydrostatic effective stress profile is near linear (Fig. F7C). These thresholds account for enlarged borehole dimensions and are based on density measurements from Sites U1319 and U1320.

Bulk density and porosity measured at the three Brazos-Trinity Basin IV sites suggest that the sediments from Hole U1321A below seismic Reflector R40 are less consolidated than those at Site U1320 but are more consolidated than those at Site U1319 (Fig. F8A). These differences in consolidation are most likely due to the difference in overburden pressure at the three sites. However, at the same vertical hydrostatic effective stress, sediments below seismic Reflector R40 at Site U1319 have lower porosity than those at Sites U1320 and U1321 (Fig. F8B). If the sediments from all sites have the same compaction properties, then under hydrostatic conditions they should all plot along the same vertical hydrostatic effective stress-porosity curve. These results could indicate un- derconsolidation at the two sites located within the basin (Sites U1321 and U1320). Deviations of these trends could be controlled by overpressure or lithologic variability.

\section{Core-log-seismic integration}

The largest variations in LWD log responses occur from 0 to $67 \mathrm{mbsf}$, an interval that corresponds to logging Subunits $1 \mathrm{a}, 1 \mathrm{~b}, 1 \mathrm{c}$, and $1 \mathrm{~d}$. These subunits are interpreted to be interbedded sand and clay layers of varying thicknesses. These variations allow extrapolation between core and seismic observations.

Four regional reflections (seismic Reflectors R10, R20, R30, and R40) mapped on high-resolution 2-D seismic data have been correlated with log data from Hole U1321A. Seismic Reflector R10 correlates with small decreases in density, resistivity, and gamma radiation within a predominantly clay rich interval, suggesting that a $\sim 2.0 \mathrm{~m}$ thick sand interval is creating the reflection (Fig. F9). Seismic Reflector R20 correlates to the base of the first sand unit $(\sim 1.5 \mathrm{~m}$ thick) within logging Subunit $1 \mathrm{~d}$ at $\sim 61.6 \mathrm{mbsf}$. This thin interval correlates with a sand layer within lithostratigraphic Unit II at Site U1320, located at 110 mbsf. Seismic Reflector R30 was picked on a trough on the seismic lines; however, the base of the turbidite succession in Hole U1321A occurs at the peak immediately above (Fig. F9). The most prominent feature within logging Unit 2 is a clay-rich layer located between 85 and 93 mbsf that is bounded by $1 \mathrm{~m}$ thick silty-sand intervals. The top of this interval correlates with seismic Reflector R40.

LWD data are linked to seismic data through a timedepth conversion. We used LWD density data (not corrected for washouts) and a constant velocity $(1600 \mathrm{~m} / \mathrm{s})$ to construct a synthetic seismogram for Hole U1320B. A $200 \mathrm{~Hz}$ minimum-phase Ricker wavelet was convolved with the reflection coefficients to create the synthetic seismogram. The correlation of events between the synthetic seismogram and the high-resolution 2-D seismic data indicates that the time-depth model is appropriate for these sediments. An accurate time-depth model allows correlation of seismic reflections with observations in core and logging data.

\section{Summary}

Site U1321 logging data provide a detailed picture of the lithofacies present at the southern edge of Brazos-Trinity Basin IV. Detailed core-log integration at Sites U1319 and U1320 will enable refinement of our preliminary interpretation, which is as follows:

- The succession below seismic Reflector R40 is composed of mud, probably laminated, with some 
minor silt beds. Three steep (dips $>60^{\circ}$, approximately east-west strike) surfaces probably represent minor faults. Borehole breakouts, oriented approximately east-west, suggest a maximum horizontal stress oriented in the north-south direction.

- Two hemipelagic intervals separate turbidite intervals at this site. These hemipelagic intervals occur immediately below seismic Reflectors R30 and R40, similar to what was observed at Sites U1319 and U1320.

- Two phases of turbidite sedimentation are interpreted. The first phase occurs between the two hemipelagic intervals within logging Unit 2 (78-
$87.5 \mathrm{mbsf}$ ) and is dominated by mud. This distal muddy turbidite phase corresponds to the initial infill of the basin. The second phase of turbidite infill in the basin corresponds to logging Unit 1, with five sand packages interbedded with muds. These sand packages are interpreted to represent depositional lobes that advanced all the way to the basin edge and in one case amalgamated to form a $25 \mathrm{~m}$ thick sand. This sand Package P3 corresponds to a completely transparent acoustic facies above seismic Reflector R20.

Publication: 8 July 2006

MS 308-105 
Figure F1. Reflection seismic section of dip Line 3020 in the immediate vicinity of Site U1321, showing positions of seismic Reflectors R10 through R60 and the seafloor reflector (SF). See also Table T1 in the "Site U1319" chapter.

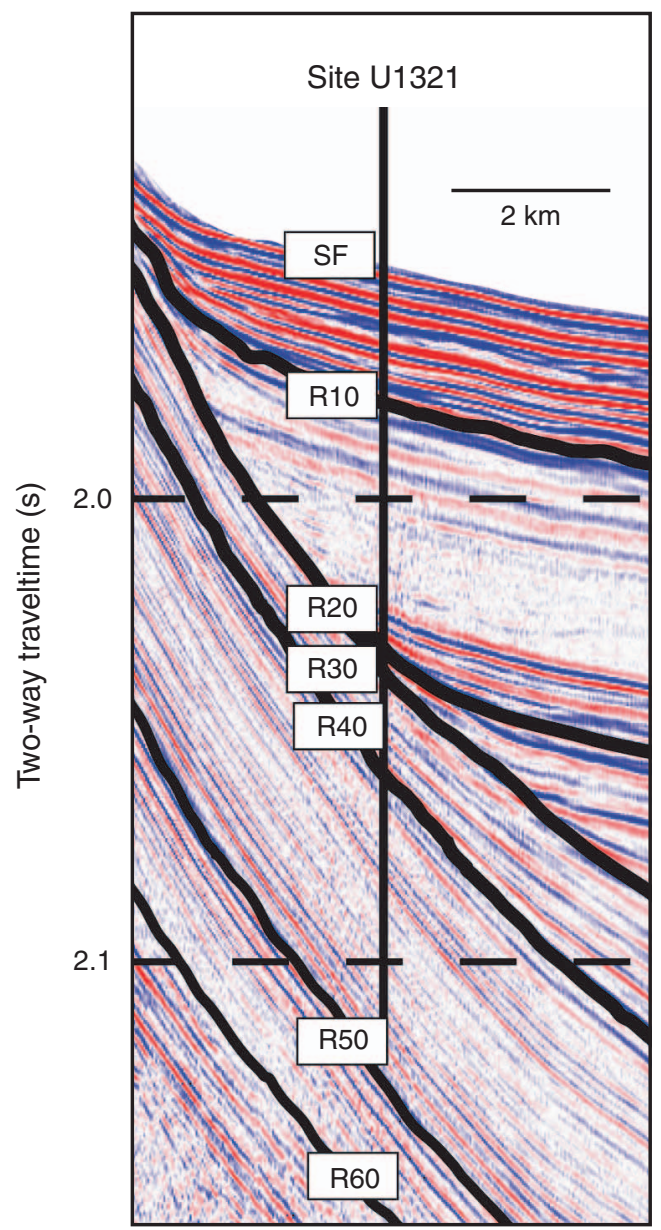


Figure F2. Data quality of curves for LWD/MWD measurements from Hole U1321A showing the rate of penetration (ROP), density-derived caliper, and density correction based on hole diameter.
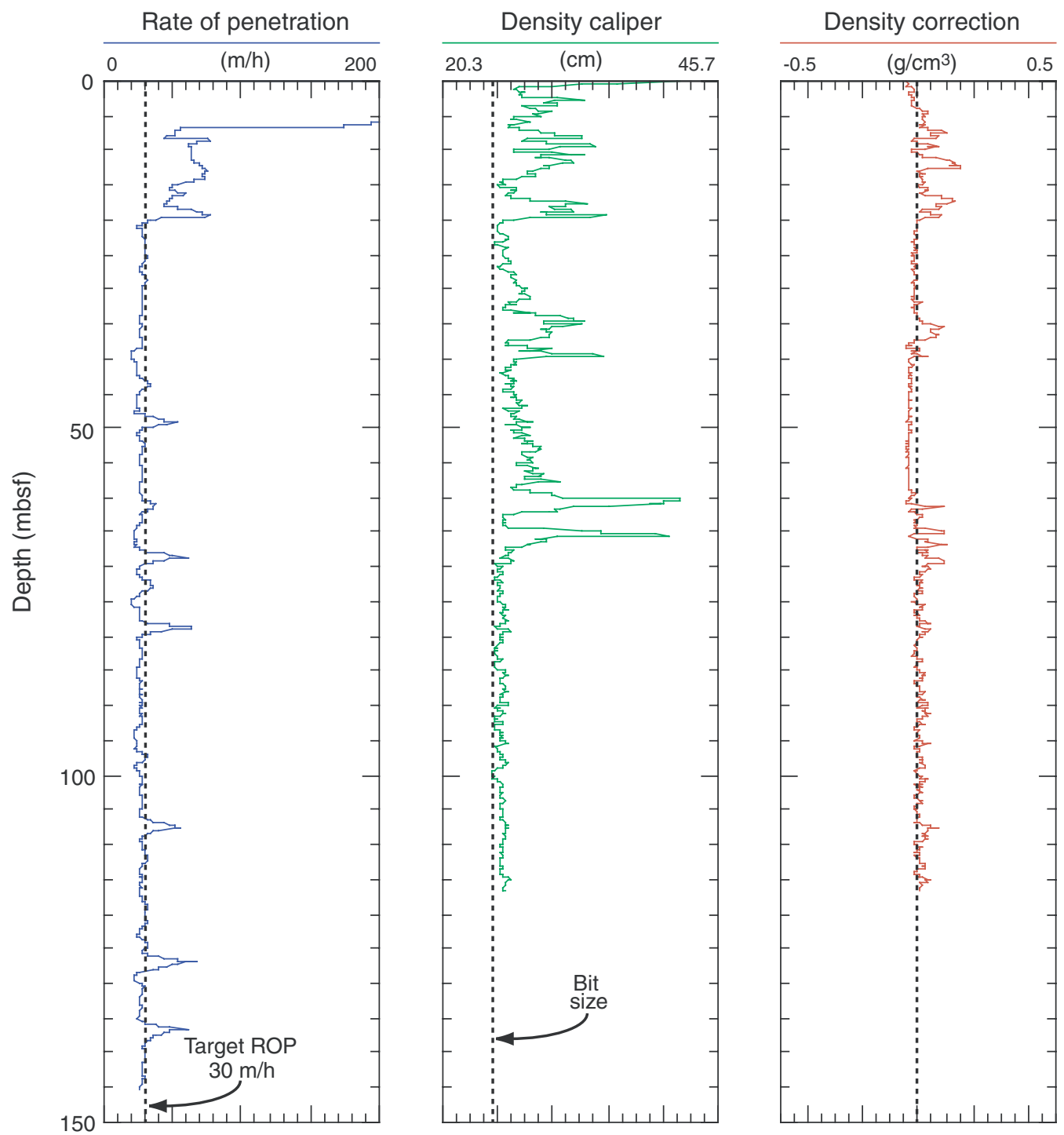
Figure F3. Caliper, gamma ray, annular pressure while drilling (APWD), annular pressure in excess of hydrostatic $\left(\mathrm{APWD}^{*}\right)$, and equivalent circulating density referenced to the seafloor $\left(\mathrm{ECD}_{\mathrm{rs}}\right)$, extracted 2-D seismic traces and seismic reflectors ( $\mathrm{SF}=$ seafloor) in Hole U1321A. Near-linear increase in APWD, especially below 67 mbsf, is interpreted as stable borehole conditions without shallow-water flow problems. Variations in APWD*, $\mathrm{ECD}_{\mathrm{rs},}$, and caliper measurements are interpreted to be due to loose material filling the borehole annulus, especially when encountering sand-rich intervals.

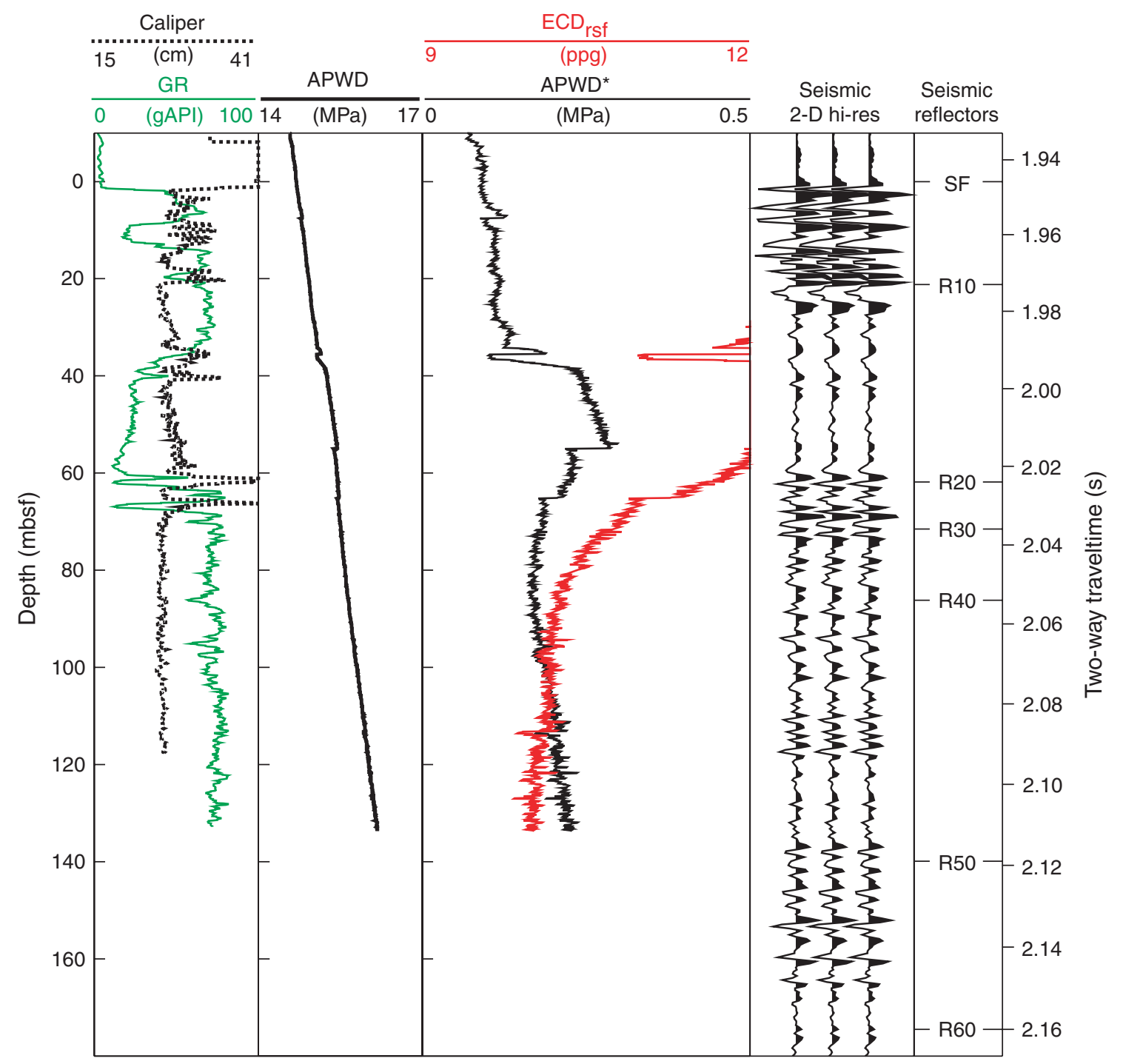


Figure F4. LWD logs recorded in Hole U1321A. Density caliper, photoelectric factor, and neutron porosity were recorded with the VDN tool, whereas gamma ray and resistivity measurements were obtained with the GVR tool. Superimposed on the PEF log is a five-point average curve. A log-based lithologic column is shown on the right. Logging units are shown in yellow (Unit 1) and green (Unit 2). Logging subunit boundaries are denoted with dashed lines.

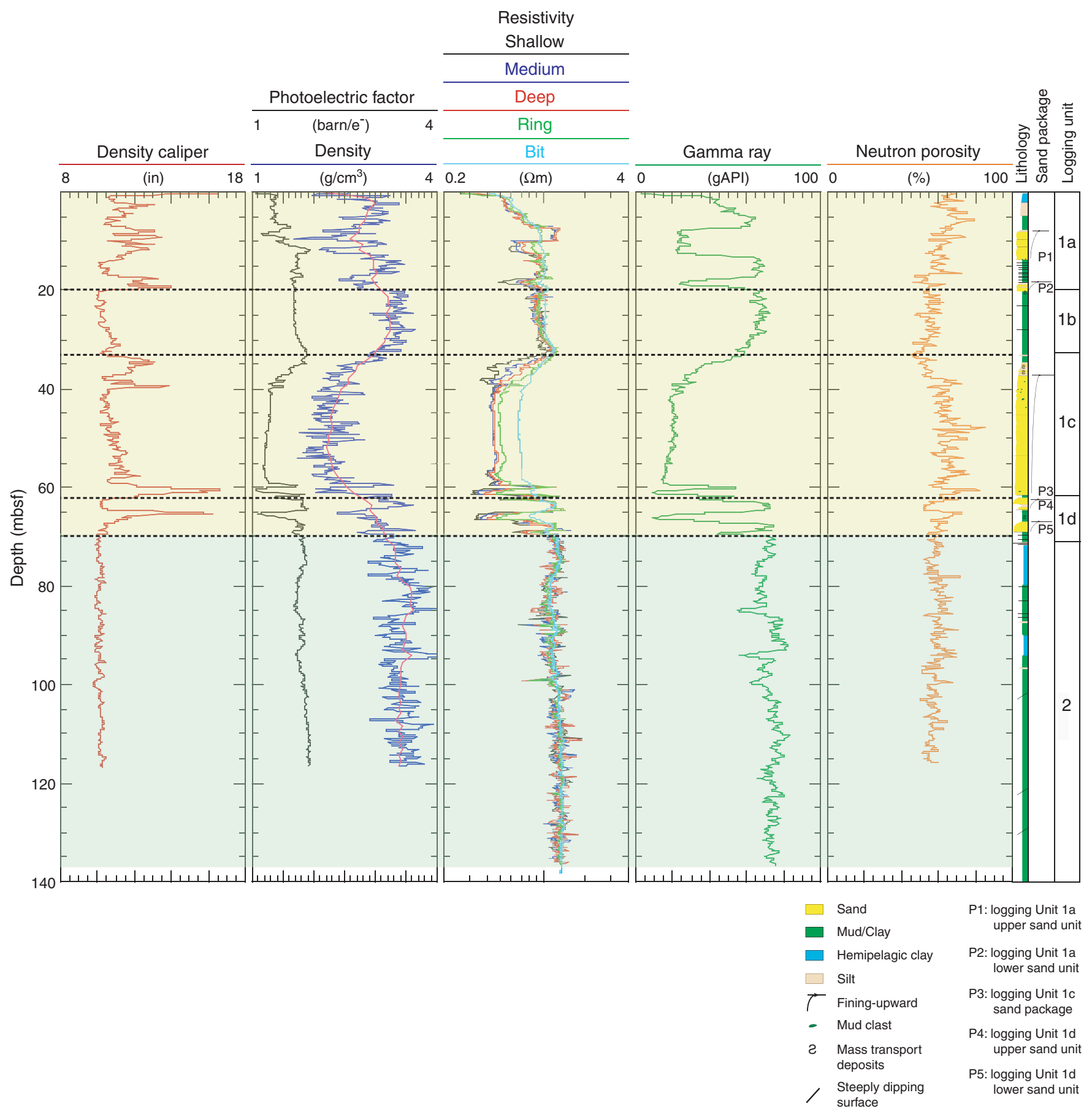


Figure F5. Summary diagram of Hole U1321A. Static and dynamic normalized resistivity-at-the-bit (GVR) images for Hole U1321A. Gamma ray (GR; green) and RING (red) resistivity (RES) logs are overlain on the static and dynamic resistivity images. The third column shows the gamma ray and RING resistivity (resistivity on reversed scale) data to highlight lithology. Seismic reflectors and extracted 2-D seismic trace are plotted in columns 4 and 5. Log-based lithology is identified. Boxes on resistivity images identify sections shown in Figure F6. SF = seafloor.

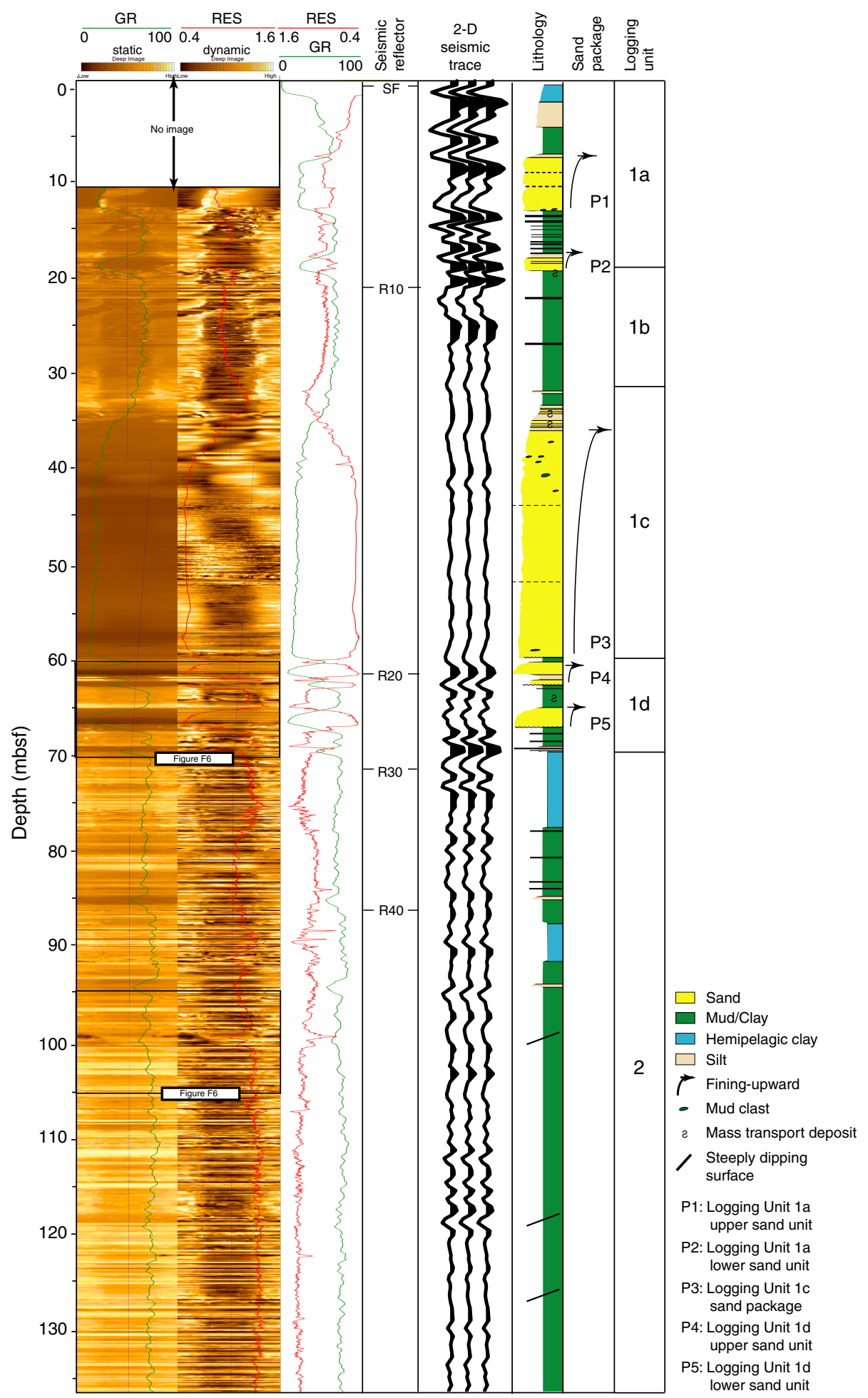


Figure F6. A. GVR image showing interbedded sand and mud/clay beds characteristic of logging Subunit 1d. Dark bands (static GVR image) with low gamma ray and low resistivity response are interpreted as sand beds with intervening mud intervals. B. GVR image showing dipping surface, probably a fault, cutting logging Unit 2.
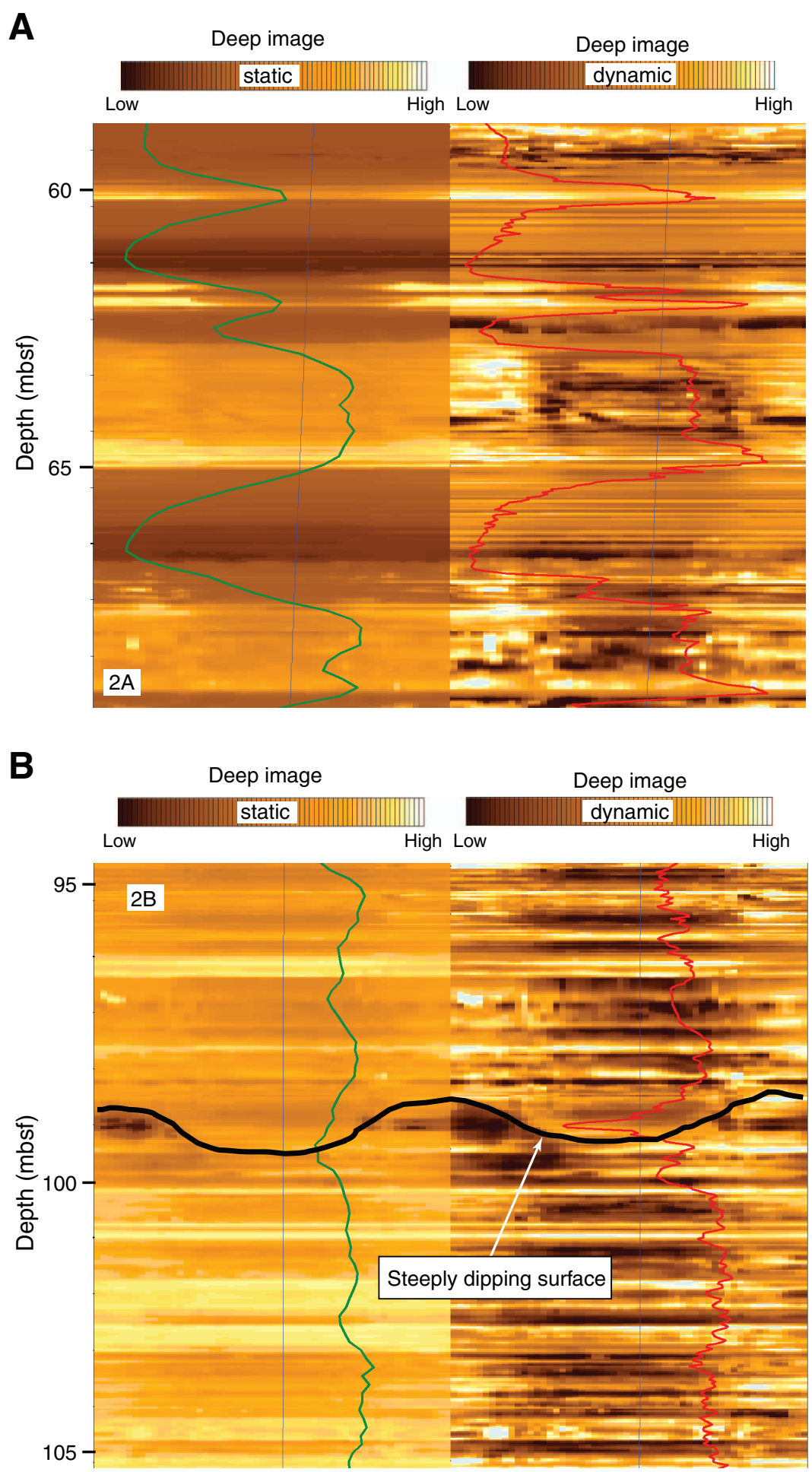
Figure F7. A. LWD bulk density data and derived porosity. Dashed line = threshold densities used to calculate a vertical hydrostatic effective stress $\left(\sigma_{\mathrm{vh}}{ }^{\prime}\right)$ profile, shown in C. The densities used for the thresholds in the upper $20 \mathrm{~m}$ and below 20 mbsf are based on results at Sites U1319 and U1320. B. Caliper (hole diameter), gamma radiation, and RING resistivity measured from LWD data. C. Vertical hydrostatic effective stress. Dashed line shows the vertical hydrostatic effective stress derived from densities above determined thresholds shown in A.

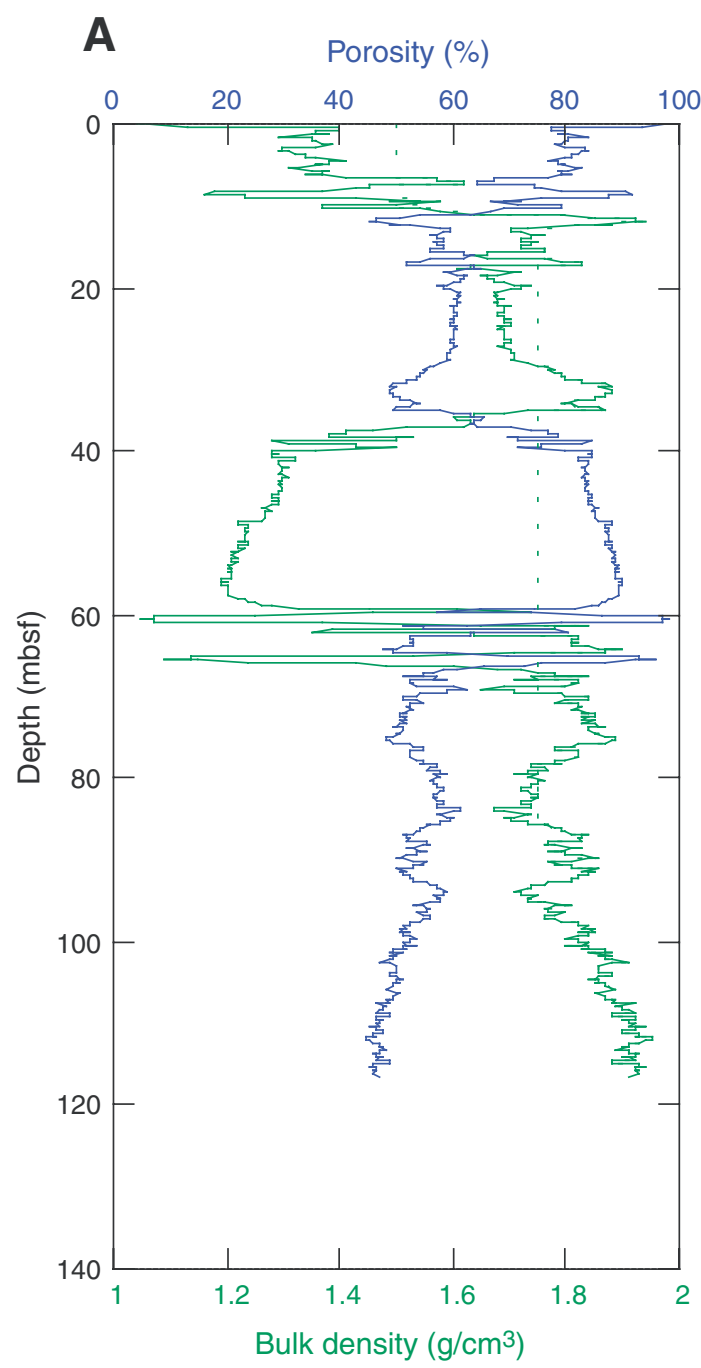

B

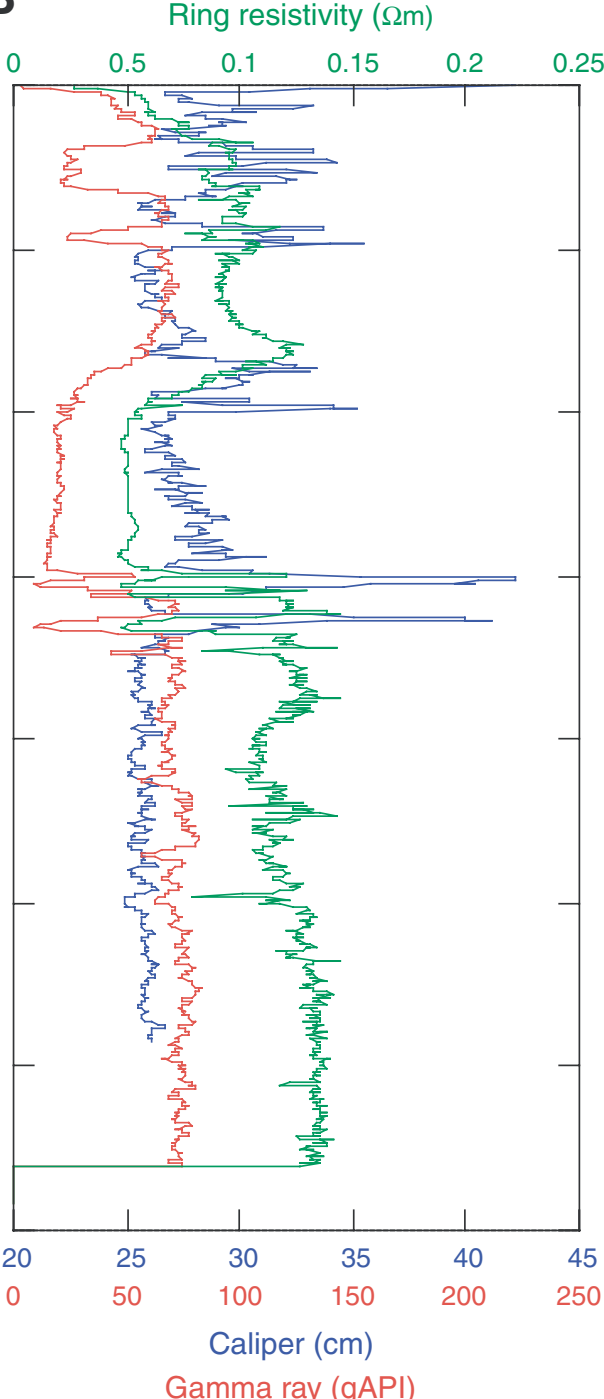

C Vertical hydrostatic effective stress (kPa)

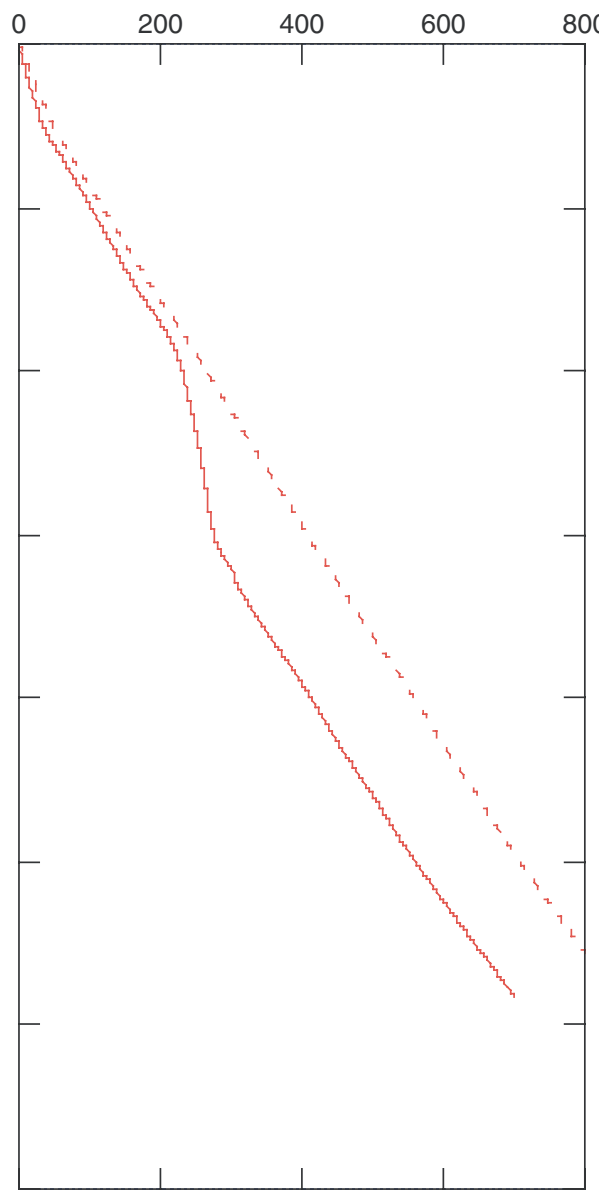




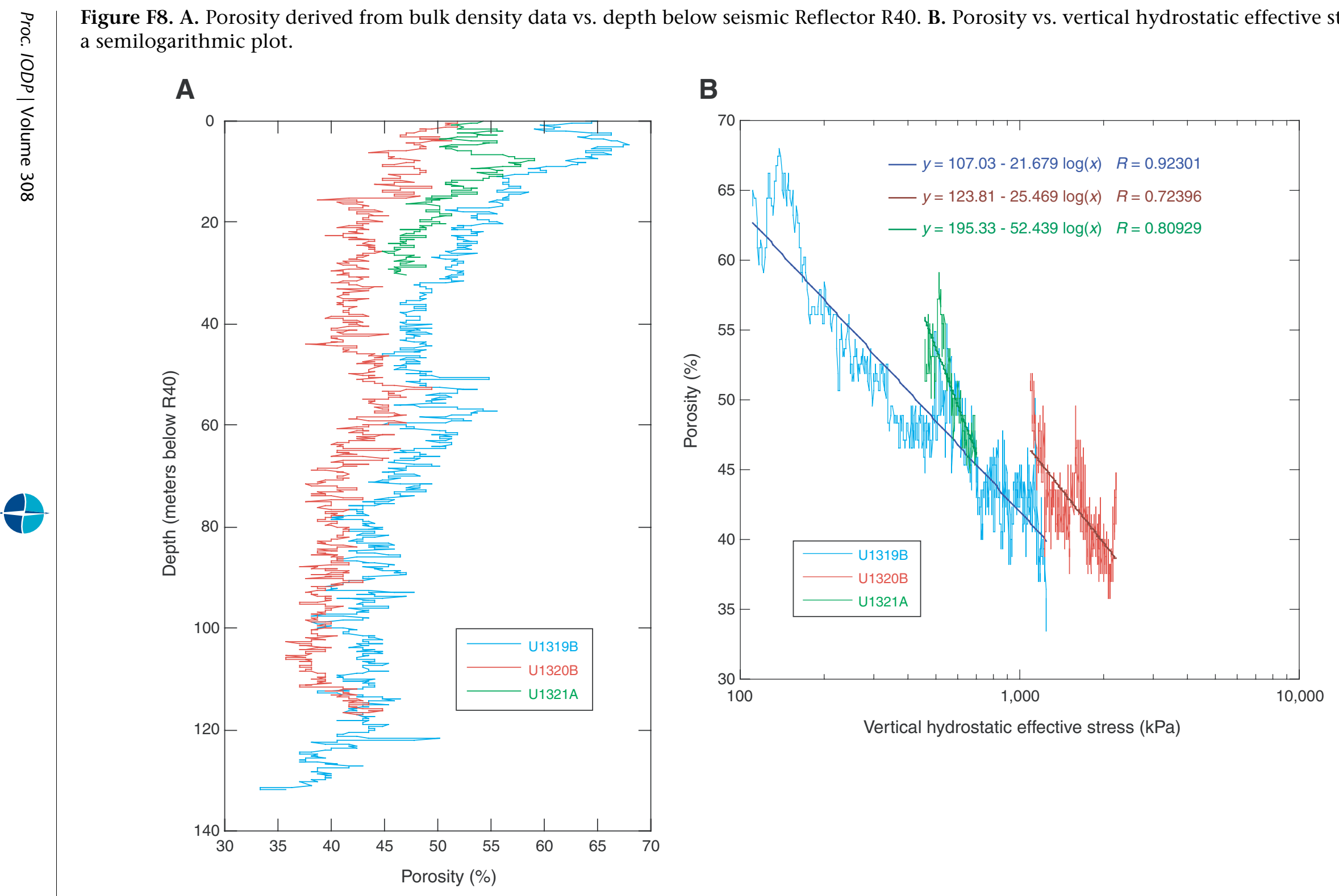


Figure F9. Core-log-seismic correlation for Site U1321. Synthetic seismogram was constructed by convolving a $200 \mathrm{~Hz}$ minimum-phase Ricker wavelet with the reflection coefficient series based on LWD bulk density (not corrected for washouts) and a constant velocity $(1600 \mathrm{~m} / \mathrm{s})$. A seismic is extracted from 2-D high-resolution multichannel seismic trace data at the location of Site U1321. Caliper, gamma ray (GR), and resistivity logs are also plotted. $\mathrm{SF}=$ seafloor.

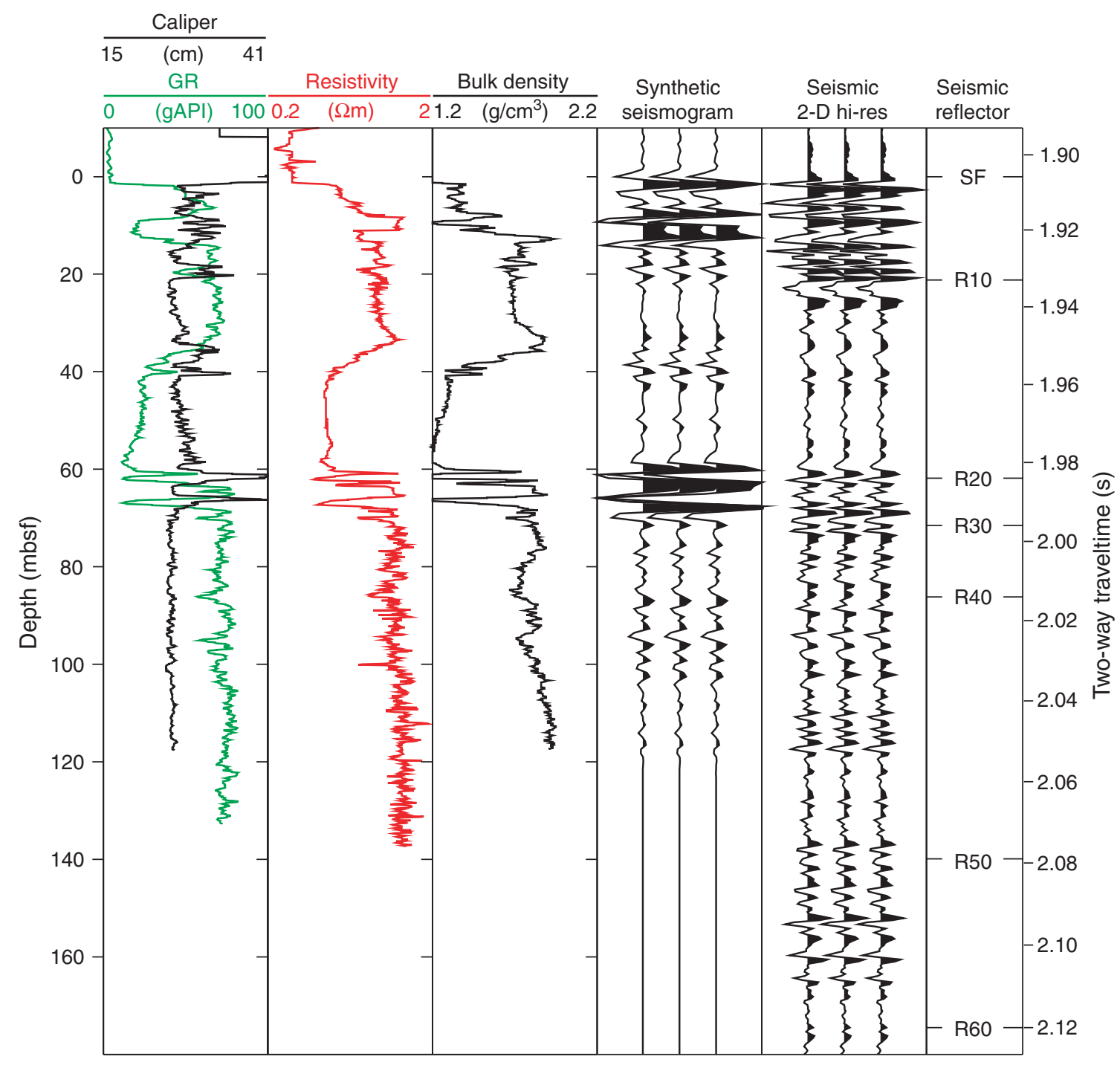


Table T1. Coring summary, Hole U1321A.

Hole U1321A

Latitude: $27^{\circ} 16.5398^{\prime} \mathrm{N}$

Longitude: $94^{\circ} 23.9370^{\prime} \mathrm{W}$

Time on site (h): 10.95

Seafloor (drill pipe measurement from rig floor, mbrf): 1462

Distance between rig floor and sea level $(\mathrm{m}): 10.5$

Water depth (drill pipe measurement from sea level, $\mathrm{m}$ ): 1451.5

Total depth (drill pipe measurement from rig floor, mbrf): 1602

Total penetration (meters below seafloor, mbsf): 140

Total length of cored section: 0

Total core recovered: 0

Core recovery (\%): 0

Total number of cores: 0

\begin{tabular}{|c|c|c|c|c|c|c|c|}
\hline \multirow[b]{2}{*}{ Core } & \multirow{2}{*}{$\begin{array}{c}\text { Date } \\
\text { (Jun 2005) }\end{array}$} & \multirow{2}{*}{$\begin{array}{l}\text { Local time } \\
\text { (h) }\end{array}$} & \multicolumn{2}{|c|}{ Depth (mbsf) } & \multicolumn{2}{|c|}{ Length $(\mathrm{m})$} & \multirow{2}{*}{$\begin{array}{c}\text { Recovery } \\
(\%)\end{array}$} \\
\hline & & & Top & Bottom & Cored & Recovered & \\
\hline \multicolumn{8}{|c|}{ 308-U1321A- } \\
\hline $1-0$ & 13 & 0915 & 0 & 140 & 0 & 0 & 0 \\
\hline & & & \multicolumn{2}{|c|}{ Cored totals: } & 0 & 0 & 0 \\
\hline
\end{tabular}

Table T2. Logging units and sand percentages, Site U1321.

\begin{tabular}{lccrr}
\hline \multirow{2}{*}{$\begin{array}{l}\text { Logging } \\
\text { unit }\end{array}$} & \multicolumn{2}{c}{ Depth (mbsf) } & Thickness & $\begin{array}{c}\text { Sand } \\
(\%)\end{array}$ \\
\cline { 2 - 3 }$(\mathrm{m})$ & Bottom & \multicolumn{1}{c}{ Top } \\
\hline 1 & 00.0 & 70.5 & 70.5 & 60 \\
1a & 00.0 & 20.0 & 20.0 & 46 \\
1b & 20.0 & 32.5 & 12.5 & 3 \\
1c & 32.5 & 60.5 & 28.0 & 100 \\
1d & 60.5 & 70.5 & 10.0 & 57 \\
2 & 70.5 & 140.0 & 69.5 & 2 \\
\hline
\end{tabular}

